Volume 2 Nomor 1, Mei 2021: h. 1 - 15

P-ISSN: 2722-4465, E-ISSN: 2746-8151

Lisensi Creative Commons Atribusi-NonCommercial 4.0 Internasional

\title{
Kekuatan Hukum MoU Dari Segi Hukum Perjanjian
}

\section{Ronald Fadly Sopamena}

Fakultas Hukum Universitas Pattimura, Ambon, Indonesia.

E-mail: rfsopamena@gmail.com

\begin{tabular}{|c|c|}
\hline Dikirim: 14/12/2020 & Dipublikasi: 31/05/2021 \\
\hline Info Artikel & Abstract \\
\hline \multirow[t]{2}{*}{$\begin{array}{l}\text { Keywords: } \\
\text { Legal Force; Momerandum } \\
\text { of Understanding; Legal } \\
\text { Agreement }\end{array}$} & $\begin{array}{l}\text { Prior to a business transaction, initial negotiations are usually carried } \\
\text { out. Negotiation is a process of trying to reach an agreement with other } \\
\text { parties. Negotiation is also an instrument that bridges the various } \\
\text { interests of business actors in formulating their rights and obligations. } \\
\text { It is in this negotiation that the bargaining process takes place. The } \\
\text { next stage is the making of a memorandum of understanding, which } \\
\text { in this writing is abbreviated as MoU. This study aims to examine } \\
\text { whether the MoU can be used as a preliminary agreement as well as } \\
\text { the legal strength of the MoU in terms of contract law. This research } \\
\text { methodology uses normative legal tracing, primary and secondary } \\
\text { legal materials with a statutory approach and a conceptual approach. } \\
\text { Based on the research results, in a business contract, the negotiations } \\
\text { carried out by the parties are outlined in the Mou as the initial } \\
\text { agreement. If in the preliminary agreement stage there is a cancellation } \\
\text { unilaterally, then as a legal consequence, the party making the } \\
\text { cancellation must be responsible for the losses incurred. This form of } \\
\text { responsibility is in the form of refunding costs incurred during } \\
\text { negotiations and compensation for lost opportunities to enter into } \\
\text { contracts with third parties. }\end{array}$ \\
\hline & Abstrak \\
\hline $\begin{array}{l}\text { Kata Kunci: } \\
\text { Kekuatan Hukum; } \\
\text { Momerandum Of } \\
\text { Understanding, Hukum } \\
\text { Perjanjian. }\end{array}$ & $\begin{array}{l}\text { Sebelum transaksi bisnis berlangsung, biasanya terlebih dahulu } \\
\text { dilakukan negosiasi awal. Negosiasi merupakan suatu proses } \\
\text { upaya untuk mencapai kesepakatan dengan pihak lain. } \\
\text { Negosiasi juga merupakan instrumen yang menjembatani } \\
\text { berbagai kepentingan pelaku bisnis dalam merumuskan hak } \\
\text { dan kewajibannya. Dalam negosiasi inilah proses tawar } \\
\text { menawar berlangsung. Tahapan berikutnya adalah pembuatan } \\
\text { memorandum of understanding yang didalam penulisan ini } \\
\text { disingkat MoU. Penelitian ini bertujuan untuk mengkaji apakah } \\
\text { MoU dapat digunakan sebagai perjanjia pendahuluan serta } \\
\text { kekuatan hukum MoU dari segi hukum perjanjian. Metodologi } \\
\text { penelitian ini menggunakan penelusuran hukum normatif, } \\
\text { bahan hukum primer dan sekunder dengan pendekatan } \\
\text { undang-undang dan pendekatan konseptual. Berdasarkan hasil } \\
\text { penelitian, Dalam kontrak bisnis, negosiasi yang dilakukan } \\
\text { para pihak dituangkan dalam MoU sebagai perjanjian awal. } \\
\text { Jika dalam tahap perjanjian pendahuluan terjadi pembatalan } \\
\text { secara sepihak, maka sebagai akibat hukumnya, pihak yang } \\
\text { melakukan pembatalan tersebut harus bertanggung jawab atas }\end{array}$ \\
\hline
\end{tabular}




\section{Pendahuluan}

Hukum kontrak merupakan bagian dari hukum perikatan. Bahkan sebagian ahli hukum menempatkan sebagai bagian dari hukum perjanjian karena kontrak sendiri ditempatkan sebagai perjanjian tertulis. Penggunaan istilah kontrak sering digunakan pada lapangan hukum bisnis dan sifat kontrak sendiri adalah perjanjian yang tertulis tetapi penulis tidak ingin membedakan antara hukum kontrak dan hukum perjanjian sehingga dalam penulisan ini pun keduannya dipergunakan sebagai makna yang sama. Istilah hukum kontrak tidak dikenal dalam KUH Perdata karena dalam KUH Perdata hanya dikenal perikatan yang lahir dari perjanjian dan yang lahir dari undang-undang.

Di dunia bisnis, waktu dan kepastian merupakan faktor yang penting. Hukum kontrak dalam hal ini memberikan sarana yang memungkinkan para pihak mengakomodasi seluruh kepentingannya. Kontrak merupakan janji yang mengikat dan janji-janji tersebut menimbulkan harapan-harapan yang layak. Hukum kontrak dalam hal ini merupakan instrumen hukum yang berfungsi untuk menjamin pelaksanaan janji dan harapan itu (Simamora, 2009: 32-33).

Menurut (Fuady, 1999: 3) memang ada fenomena bahwa hukum kontrak dianggap sebagai "keranjang sampah" (catch all). Hal ini tidak hanya terjadi di Indonesia, tetapi juga di negara lain. Yang dimaksud, dengan fenomena, hukum kontrak sebagai keranjang sampah adalah banyak hal tentang dan sekitar kontrak tidak diatur baik dalam undang-undang ataupun, dalam yurisprudensi. Kalaupun diatur, tidak selamanya bersifat memaksa, dalam arti para pihak dapat mengenyampingkannya dengan aturan yang dibuatnya sendiri oleh para pihak. Pengaturan sendiri oleh para pihak ini dituangkan dalam kontrak tersebut berdasarkan prinsip kebebasan berkontrak. Pengaturan sendiri dalam kontrak oleh para pihak sama kekuatannya dengan hukum yang sama dengan undang-undang. Para pihak dapat mengatur apapun dalam kontrak tersebut (catch all), sebatas yang tidak dilarang oleh undang-undang, yurisprudensi dan kepatutan jadi kontrak tersebut akhimya memang berkedudukan seperti keranjang sampah saja.

Pelaksanaan suatu kontrak, asas kekuatan mengikat terkadang sukar untuk dilaksanakan bila terjadi perubahan keadaan, dan perubahan tersebut sangat mempengaruhi kemampuan para pihak yang terikat dalam perjanjian untuk memenuhi prestasinya. Perubahan keadaan itu seringkali dapat menyebabkan salah satu atau lebih pihak dalam perjanjian mengalami kerugian apabila perjanjian dilaksanakan (Tjoanda et al., 2021: 95), sehingga perubahan keadaan dalam perjanjian sangat berpengaruh terhadap pelaksanaan perjanjian yang ditetapkan dan disepakati oleh para pihak, sebab perjanjian tersebut mengikat para pihak, sehingga para pihak tunduk pada isi perjanjian (Kunarso \& Sumaryanto, 2020: 33).

Sebelum transaksi bisnis berlangsung, biasanya terlebih dahulu dilakukan negosiasi awal. Negosiasi merupakan suatu proses upaya untuk mencapai kesepakatan dengan pihak lain. Negosiasi juga merupakan instrumen yang menjembatani berbagai kepentingan pelaku bisnis dalam merumuskan hak dan kewajibannya, dalam negosiasi inilah proses tawar 
menawar berlangsung. Tahapan berikutnya adalah pembuatan memorandum of understanding yang didalam penulisan ini disingkat MoU.

MoU merupakan pencatatan atau pendokumentasian hasil negosiasi awal tersebut dalam bentuk tertulis. MoU juga biasanya terlihat mirip dengan kontrak karena beberapa karakteristik yang juga menyerupai kontrak (Widjaja, 2017: 60) MoU penting sebagai pegangan untuk digunakan lebih lanjut di dalam negosiasi lanjutan atau sebagai dasar untuk melakukan studi kelayakan. Maksudnya sebagai studi kelayakan adalah setelah pihak-pihak memperoleh $\mathrm{MoU}$ sebagai pegangan atau pedoman awal, baru dilanjutkan dengan tahapan studi kelayakan (feasibility study, due diligent) untuk melihat tingkat kelayakan dan prospek transaksi bisnis tersebut dari berbagai sudut pandang yang diperlukan misalnya ekonomi, keuangan, pemasaran, teknik, lingkungan, sosial budaya dan hukum. Hasil studi kelayakan ini diperlukan dalam menilai apakah perlu atau tidaknya melanjutkan transaksi atau negosiasi lanjutan.

MoU sebenarnya tidak dikenal dalam hukum konvensional di Indonesia, terutama dalam hukum kontrak di Indonesia. Di dalam peraturan perundang-undangan Indonesia, tidak ada ketentuan yang secara khusus mengatur mengenai MoU. Adapun dasar berlakunya MoU di Indonesia adalah didasarkan pada asas kebebasan berkontrak. Selain asas kebebasan berkontrak, salah satu asas yang menjadi dasar berlakunya MoU di Indonesia adalah asas kebiasaan, yang dimaksud dengan asas kebiasaan bahwa suatu perjanjian tidak hanya mengikat untuk apa yang secara tegas diatur, akan tetapi juga hal-hal yang menurut kebiasaan lazim diikuti.

Dewasa ini, MoU sering dipraktekkan dengan meniru atau mengadopsi apa yang dipraktekkan secara internasional. Jadi sebenarnya dengan kita memberlakukan MoU, berarti kita telah ikut memperkaya khasanah pranata hukum di Indonesia ini, khususnya dalam lapangan hukum bisnis. Berdasarkan uraian tersebut, maka penulis mengangkat permasalahan.

\section{Metode Penelitian}

Jenis penelitian dalam Penelitian ini adalah penelitian normative atau penelitian hukum kepustakaan. Peter Mahmud Marzuki, mengatakan bahwa penelitian hukum adalah sesuatu proses untuk menemukan aturan hukum, prinsip-prinsip hukum maupun doktrindoktrin hukum guna menjawab isu hukum yang di hadapi (Marzuki, 2016: 35). Adapun tipe penelitian yang digunakan dalam penelitian bersifat deskritif analitis dengan menggunakan pendekatan yuridis normatif dirumuskan dalam hasil penelitian kepustakaan dan data yang diperoleh akan dianalisi dan di kaji dalam suatu sistem penelitian yang terstruktur, sehingg dengan hasil tersebut akan ditarik kesimpulannya dan dilengkapi dengan saran-saran.

\section{Hasil dan Pembahasan}

\subsection{MoU Merupakan Perjanjian Pendahuluan Dan Sebagai Bagian Dari Perjanjian}

Menyusun suatu kontrak bisnis yang baik diperlukan adanya persiapan atau perencanaan terlebih dahulu. Idealnya sejak negosiasi bisnis persiapan tersebut sudah dimulai. Penyusunan suatu kontrak bisnis meliputi beberapa tahapn sebagai berikut (Marbun, 2009: 13):

1) Prakontrak yang mencakup proses:

a) Negosiasi

b) Memorandum of Understanding (MoU) 
c) Studi kelayakan

d) Negosiasi (lanjutan).

2) Kontrak
a) Penulisan naskah awal
b) Perbaikan naskah
c) Penulisan naskah akhir
d) Penandatanganan.

3) Pasca kontrak
a) Pelaksanaan
b) Penafsiran
c) Penyelesaian sengketa.

Tahap prakontraktual merupakan bagian penting dalam pembentukan Kontrak Bisnis, Black's Law Dictionary menyatakan bahwa: "Precontractual is a contract that precludes a party from entering into comparable agreement with someone else" Jadi dalam hal ini tahapan prakontraktual dilaksanakan untuk membatasi para pihak yang telah mengadakan persetujuan untuk dapat membuat persetujuan lain yang sebanding dengan pihak ketiga. Sengketa bisnis dalam kontrak komersial seringkali berawal dari kesalahan mendasar dalam proses terbentuknya kontrak dengan berbagai faktor atau penyebabnya, antara lain (Hernoko, 2008: 276):

a) Ketidakpahaman terhadap proses binsis yang dilakukan, kondisi ini muncul ketika pelaku bisnis semata mata terjebak pada orientasi keuntungan serta karakter coba-coba (gambling) tanpa memprediksi kemungkinan resiko yang akan menimpanya.

b) Ketidakmampuan mengenali mitra bisnisnya, tidak jarang pelaku bisnis hanya sekedar memperhatikan performa atau penampilan fisik mitra bisnisnya tanpa meneliti lebih lanjut track record dan bonafiditas. Bebarapa pelaku bisnis lokal begitu mudahnya terpaku dan tertarik untuk terlibat dengan kerjasama yang ditawarkan mitra bisnis asingnya, sematamata berasumsi ahwa orang asing selalu lebih unggul segalanya tanpa mengetahui siapa partnernya.

c) Tidak adanya legal cover yang melandasi proses bisnis mereka. Hal ini menunjukkan rendahnya pemahaman apresiasi hukum pelaku bisnis dalam melindungi aktifitas bisnis mereka. Oleh sebab itu, perancangan kontrak dalam tahap prakontraktual sangat penting untuk diperhatikan guna menghindari adanya sengketa dikemudian hari.

Tahap prakontraktual terjadi proses negosiasi dimana terdapat tawar menawar diantara para pihak. Negosiasi kontrak adalah satu dialog yang terselenggara sebagai suatu rangkaian pembicaraan dan komunikasi untuk mencapai suatu kesepakatan tertulis diantara dua atau lebih pihak. Negosiasi merupakan tahapan paling penting dalam proses prakontraktual, negosiasi merupakan proses sebelum terjadinya sebuah kontrak nyata yang memuat pertukaran hak dan kewajiban para pihak secara proporsional, dalam tahap prakontraktual belum terdapat hubungan hukum diantara para pihak. Didalam hubungan hukum tersebut terdapat pihak yang berhak meminta prestasi, serta terdapat pihak yang wajib melakukan prestasi. Sehingga hubungan hukum diantara para pihak baru muncul setelah para pihak telah mengadakan kesepakatan diantara mereka dalam sebuah perjanjian atau kontrak. Hubungan hukum adalah hubungan antara dua subyek hukum atau lebih dimana hak dan kewajiban disatu pihak berhadapan dengan hak dan kewajiban di pihak lain (Wignojodiputro, 1995: 38), untuk mengamankan transaksi bisnis mereka dalam tahap prakontraktual, para pihak cenderung untuk memakai dokumen-dokumen hukum. 
Dokumen yang termasuk kedalam tahapan prakontraktual menurut (Simanjuntak, 2011: 44), antara lain : Memorandum of Understanding (MoU), Letter of Intent serta Letter of Comfort.

Dokumen-dokumen yang termasuk kedalam tahapan prakontratual tersebut disebut dengan perjanjian pendahuluan atau preliminary agreement. KUH Perdata sendiri sebenarnya tidak mengenal mengenai perjanjian pendahuluan tersebut, namun dalam praktek berbisnis perjanjian pendahuluan ini seringkali digunakan sebagai sarana untuk meyakinkan para pihak akan keseriusan mereka untuk mengadakan suatu hubungan hukum.

Tahapan prakontraktual dalam prakteknya sering dituangkan dalam bentuk MoU atau LoI, yang dibuat sebagai perwujudan dari kesepahaman, itikad atau niat para pihak sebelum memasuki tahap kontraktual. MoU adalah kesepahaman akan suatu hal tertentu antara para pihak untuk kemudian dinegosiasikan lagi melalui proses perundingan sampai terjadi kesepakatan mengenai hal-hal yang spesifik dalam mengatur bagaimana para pihak melaksanakan hak dan kewajibannya, dimana hal tersebut akan dituangkan dalam kontrak.

Perjanjian pendahuluan merupakan perjanjian yang digunakan sebagai pendahuluan untuk mengadakan perjanjian lain yang lebih pasti (Simamora, 2009: 225). Jenis perjanjian ini diintrodusir ke dalam hukum Belanda (BW) oleh Rudolf Von Jhering pada tahun 1906. Sejak itulah beragam jenis perjanjian pendahuluan bermunculan dalam praktek dalam nama yang berbeda-beda sekalipun esensinya sama. Dalam usaha memahami perjanjian pendahuluan perlu telaah historis dengan melihat Hukum Romawi (Roman Law) yang merupakan akar dari lahirnya sitem civil law, termasuk Belanda dan karenanya juga Indonesia, dalam hukum Romawi tidak dikenal aturan umum tentang kontrak yang didasarkan pada konsensus sekalipun terdapat beberapa jenis kontrak yang mensyaratkan konsensus seperti jual beli dan sewa menyewa yang merupakan dua jenis perjanjian yang terpenting.

Perjanjian pendahuluan telah merupakan kelaziman dalam praktek pembuatan kontrak bisnis di Indonesia, termasuk kontrak-kontrak yang dibuat oleh pemerintah. Jenisnya dapat berupa prosedural atau material agreement. Sedangkan judul yang digunakan dalam perjanjian ini sangat beragam diantaranya yang sering digunakan adalah memorandum of understanding, letter of intent bahkan ada juga yang menggunakan judul perjanjian kerja sama atau kerja sama.

Dari sekian banyak jenis perjanjian pendahuluan, salah satunya adalah MoU yang sering dipraktekkan dalam dunia bisnis di Indonesia. Hal ini sendiri dimungkinkan berdasarkan asas kebebasan berkontrak. MoU menurut Munir Fuady adalah "Perjanjian pendahuluan, dalam arti nantinya akan diikuti dan dijabarkan dalam perjanjian lain yang mengaturnya secara detail, karena itu, MoU berisikan hal-hal yang pokok saja. Adapun mengenai lain-lain aspek dari MoU relatif sama dengan perjanjian-perjanjian lain". Sedangkan menurut Mudana I. Nyoman bahwa MoU sebagai suatu perjanjian pendahuluan, dalam arti akan diikuti perjanjian lainnya. Dengan melihat pengertian MoU berdasarkan pendapat para ahli sebelumnya, maka penulis menyetujui pendapat Munir Fuady yang mengartikan MoU sebagai perjanjian pendahuluan yang berisikan kesepakatan mengenai hal-hal pokok yang dibuat antara subjek hukum yang satu dengan subjek hukum yang lain dan menjadi dasar penyusunan kontrak dimasa yang akan datang.

Di Indonesia landasan hukum yang digunakan dalam praktik penggunaan perjanjian pendahuluan bertumpu pada prinsip kebebasan berkontrak. Dengan demikian dasar hukum yang digunakan adalah Pasal 1320 dan Pasal 1338 ayat (1) KUH Perdata. Seperti halnya asas konsensual, asas kebebasan berkontrak menemukan dasar hukumnya pada rumusan Pasal 
1320 KUH Perdata yang berbunyi sebagai berikut; untuk sahnya perjanjian-perjanjian, diperlukan empat syarat:

1) Kesepakatan mereka yang mengikatkan dirinya;

2) Kecakapan untuk membuat suatu perikatan;

3) Suatu hal tertentu;

4) Suatu sebab yang tidak terlarang.

Jika asas konsensual menemukan dasar keberadaannya pada ketentuan angka (1) dari Pasal 1320 KUH Perdata, asas kebebasan berkontrak mendapatkan dasar eksistensinya dalam rumusan angka (4) Pasal 1320 KUH Perdata. Asas kebebasan berkontrak memungkinkan para pihak untuk membuat dan mengadakan kesepakatan atau perjanjian termasuk MoU yang melahirkan kewajiban apa saja, selama dan sepanjang prestasi yang wajib dilakukan tersebut bukanlah hal yang terlarang.

Ketentuan Pasal 1337 KUH Perdata yang menyatakan bahwa: "Suatu sebab adalah terlarang, apabila dilarang oleh undang-undang, atau apabila berlawanan dengan kesusilaan baik atau ketertiban umum". Memberikan gambaran umum kepada kita semua bahwa pada dasarnya semua perjanjian termasuk MoU dapat dibuat dan diselenggarakan oleh semua orang. Hanya perjanjian yang mengandung prestasi atau kewajiban pada salah satu pihak yang melanggar undang-undang dan kesusilaan dan juga ketertiban umum saja yang dilarang.

Seseorang bebas untuk membuat perjanjian dengan pihak manapun yang dikehendakinya sebagaimana asas kebebasan berkontra, undang-undang hanya mengatur orang-orang tertentu yang tidak cakap untuk membuat perjanjian, maka setiap orang bebas untuk memilih pihak yang diinginkan untuk membuat perianjian, asalkan pihak tersebut bukan pihak yang tidak cakap, tetapi ada pembatasan terhadap asas kebebasan berkontrak tersebut. Salah satu pembatasan terhadap asas kebebasan berkontrak dapat dilihat dalam Pasal 1338 ayat (3) KUHPerdata yang menyatakan bahwa suatu perjanjian hanya dilaksanakan dengan itikad baik. Oleh karena itu para pihak tidak dapat menentukan sekehendak hatinya klausul-klausul yang terdapat dalam perjanjiian tetapi harus didasarkan dan dilaksanakan dengan itikad baik. Perjanjian yang didasarkan pada itikad buruk misalnya penipuan mempunyai akibat hukum perjanjian tersebut dapat dibatalkan (Hetharie, 2019: 32).

Pasal 1338 KUH Perdata yang menyatakan bahwa; "Semua persetujuan yang dibuat sesuai undang-undang berlaku sebagai undang-undang bagi mereka yang membuatnya", telah menjadi dasar bagi asas pacta sund servanda, dimana sebuah MoU yang dibuat dengan tidak melanggar undang-undang maupun kepatutan dan juga ketertiban umum, mengikat para pihak yang membuatnya.

Esensi perjanjian pendahuluan adalah kesepakatan dalam membuat perjanjian (agreed to agreed), dengan demikian apa yang disepakati dalam perjanjian pendahuluan belum merupakan perjanjian. Apa yang dituangkan di dalamnya belum secara rinci mengatur hak dan kewajiban bagi para pihak melainkan baru menentukan pokok-pokoknya saja. Rincian lebih lanjut dari perjanjian pendahuluan itu akan dituangkan kedalam perjanjian tertentu sesuai dengan kesepakatan mereka, misalnya jual beli, sewa menyewa atau joint venture. Jenis perjanjian yang kompleks dan realisasinya memerlukan waktu yang cukup lama untuk mempersiapkannya lazim diawali dengan perjanjian pendahuluan ini.

KUH Perdata yang menjadi sumber hukum primer untuk kontrak belumlah mengatur mengenai tahapan prakontraktual, KUH Perdata hanya mengatur ketika syarat sahnya 
sebuah kontrak yang dapat kita lihat dari Pasal 1320 KUHPerdata. Momentum terjadinya kontrakpun tidak diatur dalam KUH Perdata tersebut, apabila terjadi kasus, maka hakim akan merujuk kepada teori-teori dari para ahli tentang lahirnya sebuah kontrak.

Menurut teori kehendak (will theory), faktor yang menentukan adanya perjanjian adalah kehendak. Meskipun demikian, terdapat hubungan yang tidak terpisahkan antara kehendak dan pernyataan. "Kehendak adalah batu penjuru (dasar) dari keseluruhan hukum keperdataan", demikian dikatakan oleh Nieskens-Ipshording dalam buku (Budiono, 2006: 383). Ia selanjutnya menambahkan bahwa pengingkaran terhadap kehendak yang otonom dari orang yang melakukan tindakan/perbuatan justru tidak akan memecahkan masalah apapun, tetapi lebih dari itu akan sekaligus menafikan hukum keperdataan.

Oleh karena itu suatu kehendak harus dinyatakan. Namun apabila terdapat ketidak sesuaian antara kehendak dan pernyataan, maka tidak terbentuk suatu perjanjian. Berdasarkan teori kehendak suatu kesepakatan mengikat karena memang merupakan keinginan para pihak yang menginginkan kesepakatan itu mengikat. Para pihak sendirilah yang pada intinya menyatakan kehendaknya melalui pembuataan MoU untuk mengikatkan diri. Jadi apabila terjadi ketidaksesuaian antara kehendak dan penyataan maka kehendak dari para pihaklah yang menentukan.

Agar suatu kehendak untuk bekerjasama dalam bidang bisnis dapat menjadi perjanjian, maka kehendak tersebut harus dinyatakan baik dalam bentuk MoU maupun langsung ke dalam bentuk kontrak. Sehingga yang menjadi dasar dari terikatnya seseorang terhadap suatu perjanjian adalah apa yang dinyatakan oleh orang tersebut melalui substansi sebuah kesepakatan. Lebih lanjut menurut teori ini, jika terdapat ketidaksesuaian antara kehendak dan pernyataan, maka hal ini tidak akan menghalangi terbentuknya perjanjian.

Teori pernyataan lahir sebagai jawaban terhadap kelemahan teori kehendak (Budiono, 2006: 76). Pernyataan atau ungkapan kehendak manusia tidak memiliki kekuatan normatif. Untuk itu dapat pula dikatakan jika seseorang menyatakan akan membuat suatu kesepakatan tertentu, hal itu adalah karena ia memang berkehendak untuk itu. Namun teori ini juga memiliki kelemahan. Karena teori pernyataan hanya hanya berfokus pada pernyataan dan tidak memperhatikan kehendak seseorang. Sehingga terdapat potensi kerugian yang terjadi apabila tidak terdapat keseuaian antara kehendak dan pernyataan. Menurut teori pernyataan, pembentukan kehendak terjadi dalam ranah kejiwaan seseorang. Sehingga pihak lawan tidak mungkin mengetahui apa yang sebenarnya terdapat di dalam benak seseorang, dengan demikian suatu kehendak yang tidak dapat dikenali oleh pihak lain tidak mungkin menjadi dasar dari terbentuknya suatu perjanjian.

Teori kepercayaan berusaha untuk mengatasi kelemahan dari teori pernyataan. Oleh karena itu teori ini juga dapat dikatakan sebagai teori pernyataan yang diperlunak. Menurut teori ini, tidak semua pernyataan melahirkan perjanjian. Suatu pernyataan hanya akan melahirkan perjanjian apabila pernyataan tersebut menurut kebiasaan yang berlaku di dalam masyarakat menimbulkan kepercayaan bahwa hal yang dinyatakan memang benar dikehendaki. Atau dengan kata lain, hanya pernyataan yang disampaikan sesuai dengan keadaan tertentu (normal) yang menimbulkan perjanjian. Adalah penting bahwa pihak lawan "tidak peduli terhadap soal apakah mitra atau lawannya dalam kontrak pada saat pernyataan dibuat memang hendak terikat dan ingin tetap terikat", apa yang penting ialah bahwa atas dasar pernyataan yang dibuat seseorang berakibat mitra atau lawannya akan mengambil tindakan tertentu.

Berdasarkan teori ini maka perjanjian bergantung pada kepercayaan atau pengharapan yang muncul dari pihak lawan sebagai akibat dari pernyataan yang 
diungkapkan, dengan demikian MoU merupakan wadah sebagai tempat para pihak yang akan berbisnis menyatakan kehendaknya masing-masing (sekalipun kehendak itu masih berupa pokok-pokoknya saja dan belum mendetail) sebelum memasuki proses kontrak dimana para pihak tersebut menaruh harapan satu sama lain agar bisa diteruskan ke kontrak yang sesungguhnya. Pembuatan $\mathrm{MoU}$ tergolong dalam tahap pra kontraktual, karena MoU dibuat para pihak sebelum membuat suatu perjanjian. Pembuatan MoU tersebut dimaksudkan oleh para pihak sebagai tahap permulaan, yang dikemudian hari akan ditindak lanjuti dengan pembuatan perjanjian (Yuanitasari \& Kusmayanti, 2020: 301).

\subsection{Pembatalan Secara Sepihak Dalam Perjanjian Pendahuluan (MoU)}

Secara umum pengertian norma adalah aturan, patakon atau pedoman yang khusus mengatur tingkah laku manusia di lingkungan kehidupannya. Ada 4 jenis norma yang dikenal dalam kehidupan masyarakat yaitu norma agama yang adalah peraturan hidup yang harus diterima manusia sebagai perintah, larangan dan ajaran yang berasal dari Tuhan Yang Maha Esa, norma kesusilaan yang merupakan norma yang mengatur hidup manusia yang berlaku secara umum dan bersumber dari hati nurani manusia, norma kesopanan yang adalah norma yang timbul dari masyarakat sendiri yang mengatur pergaulan hidup sehingga masing-masing masyarakat saling menghargai dan norma hukum yang adalah peraturan-peraturan yang timbul dan dibuat oleh lembaga kekuasaan negara. Norma hukum isinya mengikat setiap orang dan pelaksanaannya dapat dipertahankan dengan segala paksakan oleh alat-alat negara sehingga norma hukum memiliki sanksi yang nyata dan tegas bagi orang yang melanggar. Dalam hukum perdata, pelanggaran norma bisa dikaitkan dengan wanprestasi, perbuatan melawan hukum dan kerugian.

Pada tahap pelaksanaan perjanjian, para pihak harus melaksanakan apa yang telah dijanjikan atau apa yang telah menjadi kewajibannya dalam perjanjian tersebut. Menurut (Miru, 2018: 67) kewajiban memenuhi apa yang telah dijanjikan itulah yang disebut dengan prestasi, sedangkan apabila satu pihak atau bahkan kedua pihak tidak melaksanakan kewajibannya sesuai dengan perjanjian yang telah dibuatnya, itulah yang disebut dengan wanprestasi.

Sebelum menjelaskan lebih lanjut tentang wanprestasi, maka terlebih dahulu dipaparkan penjelasan tentang prestasi. Menurut Mariam Darus Badrulzaman, Prestasi adalah sesuatu yang merupakan objek dari perikatan yang menjadi kewajiban dari yang berhutang dan sebaliknya menjadi hak yang berpiutang. Yang dimaksud dengan sesuatu adalah benda dalam arti luas yang berwujud maupun tidak berwujud. Mariam Darus Badrulzaman menjelaskan lebih lanjut, bahwa kualifikasi istilah prestasi di dalam Bahasa Hukum di Indonesia belum ada, untuk mengungkapkan pengertian yang terkandung dalam istilah di atas ke dalam bahasa itu memerlukan kalimat yang panjang dan kurang praktis kedengarannya. Menurut beliau, pemakaian istilah prestasi di dalam lingkup bahasa hukum Indonesia tidaklah salah, oleh karena pada umumnya istilah tersebut lazim dipergunakan. Berdasarkan pemikiran yang demikian Mariam Darul Badrulzaman di dalam bahasa Indonesia dapat langsung mempergunakannya sebagai bahasa milik sendiri.

Sedangkan menurut (Miru, 2018: 69) apa yang disebut sebagai macam-macam prestasi diatur bukan wujud prestasi, tetapi hanya cara melaksanakan prestasi, yakni:

1) Prestasi yang berupa barang, cara melaksanakannya adalah menyerahkan sesuatu (barang); prestasi berupa jasa, cara melaksanakannya adalah dengan berbuat sesuatu; 
2) Prestasi yang berupa tidak berupa sesuatu, cara pelaksanaannya adalah dengan bersikap pasif yaitu tidak berbuat sesuatu yang dilarang dalam perjanjian.

Ahmadi Miru menyatakan lagi bahwa; Walaupun pada umumnya prestasi para pihak secara tegas ditentukan dalam kontrak, prestasi tersebut juga dapat lahir karena keharusan oleh kebiasaan, kepatutan, atau undang-undang. Oleh karena itu, prestasi yang harus dilakukan oleh para pihak telah ditentukan dalam perjanjian atau diharuskan oleh kebiasaan, kepatutan atau undang-undang, tidak dilakukannya prestasi tersebut berarti telah terjadi ingkar janji atau wanprestasi. Menurut (Subekti, 2008: 43-44) apabila si berhutang (debitur) tidak melakukan apa yang dijanjikan akan dilakukannya, maka dikatakan bahwa ia melakukan "wanprestasi". Ia adalah "alpa" atau "lalai" atau "bercidera janji". Atau juga ia "melanggar perjanjian", yaitu apabila ia melakukan atau berbuat sesuatu yang tidak boleh dilakukannya.

Menurut Abdulkadir Muhammad, wanprestasi artinya tidak memenuhi kewajiban yang telah ditetapkan dalam perikatan baik perikatan yang timbul karena undang-undang maupun perikatan yang timbul karena perjanjian (Muhammad, 1990: 20), sedangkan Ahmadi Miru (Miru, 2018: 74) mengistilahkan wanprestasi dengan istilah "tidak dipenuhi janji", dan hal ini dapat terjadi karena disengaja maupun tidak disengaja. Pihak yang tidak sengaja wanprestasi ini dapat terjadi karena memang tidak mampu untuk memenuhi prestasi tersebut atau juga karena terpaksa untuk tidak mampu melakukan prestasi tersebut.

Wanprestasi dapat berupa:

1) sama sekali tidak memenuhi prestasi;

2) prestasi dilakukan tidak sempurna;

3) terlambat memenuhi prestasi;

4) melakukan apa yang dalam perjanjian dilarang untuk dilakukan.

Terjadinya wanprestasi dalam perjanjian mengakibatkan pihak lain (lawan dari pihak yang wanprestasi) mengalami kerugian, kata "kerugian" berasal dari kata "rugi" yang berarti tidak mendapat laba menurut kamus Bahasa Indonesia, sedangkan menurut Nieuwenhius adalah berkurangnya harta kekayaan pihak yang satu disebabkan oleh perbuatan (melakukan atau membiarkan) yang melanggar norma oleh pihak lain, dengan demikian dapat diketahui dengan mudah apakah arti kerugian tersebut.

Wanprestasi sebagaimana diamanahkan dalam Pasal 1238 KUHPerdata yang mengatakan: Si berutang adalah lalai, apabila ia dengan surat perintah atau dengan sebuah akta sejenis itu telah dinyatakan lalai, atau demi perikatannya sendiri, ialah jika ia menerapkan, bahwa si berutang harus dianggap lalai dengan lewatnya waktu yang ditentukan. Saat salah satu pihak telah melakukan Wanpretasi maka dimungkinkan timbulnya kerugian dalam peristiwa tersebut, sebagaimana diterangkan dalam Pasal 1243 KUH Perdata memperincikan kerugian (dalam arti luas) ke dalam tiga kategori sebagai berikut:

(1) biaya,

(2) kerugian (dalam arti sempit), dan

(3) bunga.

Yang dimaksudkan dengan biaya adalah setiap cost yang harus dikeluarkan secara nyata oleh pihak yang dirugikan, dalam hal ini sebagai akibat dari adanya tindakan wanprestasi (Fuady, 1999: 138). Misalnya dalam kontrak jual beli, dimana si penjual melakukan wanprestasi, sehingga pihak pembeli berusaha membeli barang yang sama dari pihak lain dengan harga yang lebih mahal, maka selisih harga tersebut merupakan 
komponen biaya yang mesti diganti oleh pihak penjual. Contoh lain dari komponen "biaya" ini adalah biaya perjalanan, biaya pengiriman barang, dan sebagainya. Sementara itu, yang dimaksud dengan "kerugian" (dalam arti sempit) adalah keadaan merosotnya atau berkurangnya nilai kekayaan kreditur sebagai akibat dari adanya wanprestasi yang dilakukan debitur.

Selanjutnya yang dimaksud dengan bunga adalah keuntungan yang seharusnya diperoleh tetapi tidak jadi diperoleh oleh pihak kreditur karena adanya tindakan wanprestasi dari pihak debitur. Maka dengan demikian pengertian bunga dalam Pasal 1243 menjadi lebih luas dan tidak hanya dimaksud sebagai bunga uang (interest) dalam pengertian sehari-hari, yang hanya ditentukan dengan menentukan presentase dari hutang pokok.

Kerugian terbagi atas dua bentuk yaitu kerugian materiil dan kerugian immaterial. Kerugian materiil adalah kerugian yang dapat diukur atau dinilai dengan uang. Berbeda dengan kerugian immateriil yang tidak bisa diukur dalam jumlah yang pasti. Undangundang hanya mengatur penggantian kerugian yang bersifat materiil. Kemungkinan terjadi bahwa kerugian itu menimbulkan kerugian yang immateriil, tidak berwujud, moril, idiil, tidak dapat dinilai dengan uang, tidak ekonomis, yaitu berupa sakitnya badan, penderitaan batin, rasa takut, dan sebagainya.

Terminologi perbuatan melawan hukum merupakan terjemahan dari kata onrechtmatige daad dalam bahasa Belanda atau dalam bahasa Inggris dikenal dengan istilah 'tort'. Beberapa sarjana ada yang menggunakan istilah 'melanggar' ada juga yang menggunakan istilah 'melawan' dalam menerjemahkan onrechtmatige daad. Wirjono Projodikoro, menterjemahkan kata onrechtmatige daad menjadi 'perbuatan melanggar hukum' sementara M.A. Moegni Djojodordjo, Mariam Darus Badrulzaman, Sri Soedewi Masjchoen Sofwan, I.S. Adiwimarta, dan Setiawan, menerjemahkannya menjadi 'perbuatan melawan hukum' (Agustina et al., 2012: 3).

Perbuatan melawan hukum di Indonesia secara normatif selalu merujuk pada ketentuan Pasal 1365 KUH Perdata. Rumusan norma dalam pasal ini unik, tidak seperti ketentuan-ketentuan pasal lainnya. Perumusan norma Pasal 1365 KUH Perdata lebih merupakan struktur norma dari pada substansi ketentuan hukum yang sudah lengkap. Oleh karenanya substansi ketentuan Pasal 1365 KUH Perdata senantiasa memerlukan materialisasi di luar KUH Perdata. Pasal 1365 KUH Perdata menentukan bahwa tiap perbuatan melawan hukum yang mengakibatkan kerugian pada orang lain, mewajibkan orang yang melakukan perbuatan tersebut untuk mengganti kerugian.

Perbuatan melawan hukum dalam KUH Perdata diatur dalam Pasal 1365 hingga Pasal 1380. Perbuatan melawan hukum lebih diartikan sebagai sebuah perbuatan 'melukai' (injury) daripada pelanggaran terhadap kontrak (breach ofcontract). Apalagi gugatan perbuatan melawan hukum umumnya tidak didasari dengan adanya hubungan hukum kontraktual.

\subsection{Akibat Hukum Yang Timbul Dari Pembatalan MoU Secara Sepihak}

Ketika perundingan atau negosiasi telah memasuki perjanjian pendahuluan dan menghasilkan sebuah dokumen seperti MoU, maka dokumen tersebut haruslah diteliti kembali apakah memiliki daya mengikat atau tidak, dalam praktek penerapan perjanjian pendahuluan sering terjadi inkonsistensi antara substansi dan judul perjanjiannya, dalam arti judulnya menunjukan jenis perjanjian pendahuluan, tetapi substansinya telah mencerminkan suatu perjanjian yang sebenarnya. Persoalan hukum yang mungkin timbul adalah ketika perjanjian pendahuluan itu karena suatu alasan tertentu tidak dapat 
ditindaklanjuti ke dalam suatu perjanjian dan merugikan salah satu pihak. Ada beberapa hal yang perlu diteliti untuk menentukan apakah suatu MoU dapat dikatakan suatu perjanjian atau tidak yaitu berdasarkan:

1) Materi/substansi dalam MoU

Materi atau substansi yang diatur dalam pasal-pasal MoU sangat penting untuk di teliti, karena di dalam Materi atau substansi tersebut dapat diketahui apakah hak dan kewajiban para pihak di dalam MoU tersebut sudah seimbang apa tidak, artinya didalam MoU tersebut antara hak-hak dan kewajiban para pihak telah diatur dengan terperinci atau secara detail. Sebagai dokumen yang disepakati oleh kedua belah pihak, MoU berisi kesepakatan-kesepakatan para pihak. (Mandasari, 2013). Pada prinsipnya didalam MoU hanya diatur mengenai unsur-unsur pokoknya saja, seperti objek perjanjian dan waktu perjanjian, maka MoU semacam ini berdasarkan asas obligator tidak bisa dikatakan suatu kontrak, karena belum final dalam pembuatannya.

2) Adanya Sanksi.

Teori Holmes yang menyatakan bahwa tidak ada sanksi moral dalam suatu kontrak, artinya MoU bukanlah merupakan suatu perjanjian apabila hanya memiliki sanksi moral saja. Aturan-aturan hukum di mata Holmes, hanya menjadi satu faktor yang patut dipertimbangkan dalam keputusan yang "berbobot". Faktor moral, soal kemanfaatan dan keutamaan kepentingan sosial misalnya menjadi faktor yang tidak kalah penting dalam mengambil keputusan yang "berisi" (Tanya et al., 2010: 167).

Oleh karena itu didalam MoU tersebut haruslah mengatur sanksi hukum yang tegas. Maksudnya adalah dalam proses pelaksanaan MoU apabila terjadi sengketa atau salah satu pihak tidak melaksanakan prestasinya sesuai dengan yang telah diperjanjikan, maka pihak yang dirugikan akan mendapat perlindungan hukum, dan perlindungan hukum tersebut berupa penggantian biaya kerugian atas dasar gugatan wanprestasi terhadap pihak yang tidak melaksanakan prestasinya sesuai yang diperjanjikan.

Dengan demikian MoU yang merupakan Nota Kesepahaman yang dibuat para pihak tentang suatu kesepakatan, haruslah ditindak lanjuti dengan membuat akta otentik yang di buat di hadapan notaris sebagai tindak lanjut dari MoU tersebut agar memiliki kekuatan hukum. Akan tetapi apabila dalam proses pelaksanaannya, MoU tersebut tidak ditindak lanjuti dengan membuat akta otentik yang diperbuat di hadapan notaris, maka daya mengikat dari MoU tersebut, hanya sebatas moral saja. Hal ini sesuai dengan pendapat sebahagian para ahli yang mengemukakan bahwa MoU adalah merupakan Gentlemen Agreement, maksudnya adalah kekuatan mengikatnya suatu MoU tidak sama dengan perjanjian biasa, sungguh pun MoU dibuat dalam bentuk yang paling kuat seperti dengan akta notaris sekalipun. Oleh karena itu menurut pendapat golongan ini, MoU mengikat sebatas pada pengakuan moral belaka, dalam arti tidak punya daya ikat secara hukum.

Apa yang mengikat para pihak adalah apa yang telah disepakati. Kewajiban yang dipertukarkan dalam kewajiban itulah yang merupakan kesepakatan yang mengikat. Dengan demikian yang mengikat adalah isi perjanjiannya dan bukan judulnya. Sekalipun dari judul perjanjian tercermin jenisnya perjanjian pendahuluan, misalnya MoU, namun apabila substansinya telah mencerminkan suatu perjanjian, dalam arti telah jelas diatur hubungan hukum diantara para pihak dan telah jelas pula hak dan kewajiban masingmasingnya maka tidak ada alasan untuk mengatakan bahwa persetujuan yang demikian bukanlah perjanjian. Pemahaman demikian tidak saja penting untuk kepastian hukum tetapi 
juga untuk mencegah praktek penyalahgunaan perjanjian pendahuluan, yaitu dengan memberi judul misalnya MoU untuk hubungan hukum yang sesungguhnya sudah merupakan perjanjian yang mengikat dan melahirkan kewajiban-kewajiban maupun pembuatan MoU oleh pelaku bisnis yang tidak serius yang hanya ingin sekedar main-main dan ingin terlepas dari ikatan hukum.

Dalam situasi dimana terjadi pengingkaran terhadap perjanjian pendahuluan, perlu dijawab pertanyaan apakah jenis perjanjian ini secara hukum mengikat dan karenanya melahirkan kewajiban kontraktual. Seperti telah dikemukakan, tidak ada aturan yang spesifik mengatur hal ini dalam KUH Perdata. Namun demikian syarat pembuatan perjanjian sebagaimana diatur Pasal 1320 KUH Perdata dapat diterapkan untuk mengukur apakah telah terpenuhi empat syarat yang diwajibkan, yakni kesepakatan, kecakapan, objek dan causa yang dibolehkan dalam perjanjian pendahuluan. Jika perjanjian pendahuluan yang dibentuk konsisten dengan makna aslinya maka syarat objek dan causa tidak akan terpenuhi karena dalam perjanjian pendahuluan belum secara detail mengatur hak dan kewajiban para pihak.

Tetapi jika substansi yang termuat dalam perjanjian pendahuluan itu telah mencerminkan suatu perjanjian maka perjanjian pendahuluan yang dimaksud tidak ada bedanya dengan perjanjian yang sesungguhnya dan dengan demikian berlakulah asas Pacta Sunt Servanda. Pengingkaran pada perjanjian melahirkan hak bagi pihak lain untuk mengajukan gugatan atas dasar wanprestasi.

Sebaliknya, jika perjanjian yang dimaksud memang bermakna sebagai perjanjian pendahuluan, gugatan wanprestasi tentu akan ditolak hakim (Simamora, 2009: 229), dalam situasi ini, dari perspektif hukum postif di Indonesia, bagi pihak yang dirugikan tidak ada pilihan lain kecuali menggunakan dasar gugatan perbuatan melawan hukum (onrechtmatige daad) sebagaimana yang diatur dalam Pasal 1365 KUH Perdata.

Jika salah satu pihak membuat suatu penawaran tanpa keseriusan atau salah satu pihak melakukan kesalahan sepihak dalam menyampaikan penawarannya atau salah satu pihak mengetahui hal yang tidak mungkin dilakukan, perilaku salah ini akan mengakibatkan pihak tersebut bertanggungjawab dari pihak yang tidak bersalah.

Sebagai bentuk perjanjian pendahuluan, MoU memiliki kekuatan mengikat bagi para pihak yang terlibat di dalamnya. Akan tetapi MoU hanya berisi pokok-pokok kesepakatan yang akan ditindaklanjuti dengan kontrak yang sesungguhnya sehingga belumlah jelas apa saja yang menjadi hak dan kewajiban para pihak.

Dengan demikian, ganti kerugian atas kerugian nyata yang masih mungkin untuk dipertimbangkan sebagai akibat hukum dari pembatalan secara sepihak dalam MoU adalah berdasarkan gugatan perbuatan melawan hukum, bukan wanprestasi, mengingat karena memang belum terjadi kontrak antar para pihak karena masih dalam tahapan pra kontrak. Maka tidaklah mungkin apabila terjadi wanprestasi antar para pihak. Sedangkan gugatan perbuatan melawan hukum sangat dimungkinkan mengingat unsur-unsur Pasal 1365 KUH Perdata telah terpenuhi. Pasal 1365 tersebut adalah sebagai berikut: "Setiap perbuatan melanggar hukum, yang membawa kerugian kepada orang lain, mewajibkan orang yang karena salahnya menerbitkan kerugian yang disebabkan kelalaian atau kurang hatihatinya".

Lebih lanjut perbuatan melawan hukum kemudian diartikan tidak hanya perbuatan yang melanggar kaidah-kaidah tertulis atau undang-undang, yaitu perbuatan yang bertentangan dengan kewajiban hukum si pelaku dan melanggar kaidah hak subjektif orang 
lain, tetapi juga perbuatan yang melanggar kaidah yang tidak tertulis, yaitu kaidah yang mengatur tata susila, kepatutan, ketelitian dan kehati-hatian yang seharusnya dimiliki seseorang dalam pergaulan hidup dalam masyarakat atau terhadap harta benda warga masyarakat. (Agustina et al., 2012: 8).

Sebagaimana ditegaskan dalam Pasal 1365 KUH Perdata, dalam hal seseorang melakukan suatu perbuatan melawan hukum maka dia berkewajiban membayar ganti rugi akan perbuatannya tersebut, hal yang berbeda dengan tuntutan kerugian dalam wanprestasi, dalam tuntutan Perbuatan Melawan Hukum tidak ada pengaturan yang jelas mengenai ganti kerugian tersebut namun sebagaimana diatur dalam Pasal 1371 ayat (2) KUH Perdata tersirat pedoman yang isinya "Juga penggantian kerugian ini dinilai menurut kedudukan dan kemampuan kedua belah pihak, dan menurut keadaan".

Pedoman selanjutnya mengenai ganti kerugian dalam Perbuatan Melawan Hukum kita bisa dalam Pasal 1372 ayat (2) KUH Perdata yang isinya: "Dalam menilai suatu dan lain, Hakim harus memperhatikan berat ringannya penghinaan, begitu pula pangkat, kedudukan dan kemampuan kedua belah pihak, dan pada keadaan", dalam ilmu hukum, ada tiga kategori perbuatan melawan hukum yaitu:

1) Perbuatan melawan hukum karena kesengajaan

2) Perbuatan melawan hukum tanpa kesalahan/ tanpa unsur kesengajaan maupun kelalaian, dan

3) Perbuatan melawan hukum karena kelalaian.

Maka suatu perbuatan melawan hukum harus mengandung unsur-unsur:

1) Adanya suatu perbuatan

2) Perbuatan tersebut melawan hukum

3) Adanya kesalahan dari pihak pelaku

4) Adanya kerugian bagi korban, dan

5) Adanya hubungan kausal antara perbuatan dengan kerugian. (Munir Fuadi, 2005: 2-3).

Menurut (Agustina et al., 2012: 117) dalam menentukan suatu perbuatan dapat dikualifisir sebagai perbuatan melawan hukum, diperlukan 4 syarat:

1) Bertentangan dengan kewajiban hukum pelaku

2) Bertentangan dengan hak subjektif orang lain

3) Bertentangan dengan kesusilaan

4) Bertentangan dengan kepatutan, ketelitian dan kehati-hatian.

Tanggung jawab perbuatan melawan hukum hadir untuk melindungi hak-hak seseorang. Hukum dalam perbuatan melawan hukum mengariskan hak-hak dan kewajibankewajiban saat seseorang melakukan perbuatan baik kesalahan atau kelalaian atau melukai orang lain dan perbuatan tersebut menimbulkan kerugian bagi orang lain.

Sebagai pedoman dapat dilihat ketentuan Pasal 1248 KUHPerdata yang menyebutkan bahwa pembayaran ganti rugi hanya diberikan atas kerugian yang sudah dapat diduga dan merupakan akibat langsung dari tidak terpenuhinya perikatan. Menurut ketentuan pasal 1246 KUHPerdata ada tiga macam ganti rugi yang dapat diajukan oleh penggugat terhadap tergugat yaitu biaya, rugi dan bunga.

Kerugian yang diderita seseorang secara garis besar dapat dibagi atas dua bagian, yaitu kerugian yaitu kerugian yang menimpa diri dan kerugian menimpa harta benda 
seseorang (Miru, 2018: 80). Pada umumnya kerugian diperhitungkan dalam sejumlah uang tertentu (Satrio, 1993: 152).

Ganti rugi yang dapat dibebankan terhadap perbuatan melanggar hukum adalah atas kerugian nyata yang memang ditimbulkan oleh perbuatan tersebut (reliance loss). Ganti rugi tersebut bertujuan untuk menempatkan penggugat pada posisinya semula seandainya tidak terdapat perbuatan melanggar hukum tersebut, dengan demikian maka dalam pembatalan MoU secara sepihak, pihak yang dirugikan bisa menggugat ganti rugi atas biaya atau ongkos yang telah dikeluarkan. Hal ini bertujuan agar bisa membawa keadaan pihak yang dirugikan bisa dikembalikan seperti semula sebelum MoU dibuat.

\section{Kesimpulan}

Pembuatan kontrak bisnis pada umumnya diawali dengan negosiasi yang dilakukan oleh para pihak kemudian dituangkan dalam sebuah MoU yang merupakan perjanjian pendahuluan yang dibuat sebagai perwujudan dari kesepahaman dan kehendak para pihak sebelum memasuki tahap kontraktual. Hal tersebut disebabkan karena struktur dan anatomi MoU sama dengan perjanjian. Sehingga MoU tunduk pada prinsip, asas dan norma hukum perjanjian yang diatur di dalam Buku III KUH perdata. Jika dalam tahap perjanjian pendahuluan terjadi pembatalan secara sepihak, maka sebagai akibat hukumnya, pihak yang melakukan pembatalan tersebut harus bertanggung jawab atas kerugian yang ditimbulkannya. Bentuk tanggung jawab tersebut berupa pengembalian biaya yang telah dikeluarkan pada saat melakukan negosiasi dan ganti rugi atas kehilangan kesempatan untuk melakukan kontrak dengan pihak ketiga.

\section{Daftar Referensi}

Agustina, R., Suharnoko, Nieuwenhuis, H., \& Hijma, J. (2012). Hukum Perikatan (Law of Obligations). Pustaka Larasan.

Budiono, H. (2006). Asas Keseimbangan bagi Hukum Perjanjian Indonesia. Citra Aditya Bakti.

Fuady, M. (1999). Hukum Kontrak, Dari Sudut Pandang Hukum Bisnis. Citra Aditya Bakti.

Hernoko, A. Y. (2010). Hukum Perjanjian: Asas Proposionalitas dalam Kontrak Komersial. Prenada Media Group.

Hetharie, Y. (2019). Perjanjian Nominee sebagai Sarana Penguasaan Hak Milik atas Tanah oleh Warga Negara Asing (WNA) Menurut Kitab Undang-Undang Hukum Perdata. SASI, 25(1), 27-38. https:/ / doi.org/10.47268/ sasi.v25i1.147

Kunarso, \& Sumaryanto, A. D. (2020). Eksistensi Perjanjian Ditengah Pandemi Covid-19. Batulis Civil Law Review, 1(1), 33-46. https:/ / doi.org/10.47268/ballrev.v1i1.423

Mandasari, Z. (2013). Kedudukan Memorandum of Understanding dan Surat Keputusan Bersama Ditinjau dari Teori Perundang-Undangan. Jurnal Hukum Ius Quia Iustum, 20(2), 278-299. https:// doi.org/10.20885/iustum.vol20.iss2.art6

Marbun, B. N. (2009). Membuat Perjanjian yang Aman dan Sesuai Hukum. Puspa Swara.

Marzuki, P. M. (2016). Penelitian Hukum,. Kencana. https:/ / doi.org/340.072

Miru, A. (2018). Hukum Kontrak \& Perancangan Kontrak. Rajawali Pers.

Muhammad, A. K. (1990). Hukum Perikatan. Citra Aditya Bakti. 
Satrio, J. (1993). Hukum Perikatan (Perikatan Pada Umumnya). Alumni.

Simamora, Y. S. (2009). Hukum Perjanjian; (Prinsip Hukum Kontrak Pengadaan Barang dan Jasa oleh Pemerintah). LaksBang Pressindo.

Simanjuntak, R. (2011). Hukum Kontrak: Teknik Perancangan Kontrak Bisnis. Publishing.

Subekti. (2008). Hukum Perjanjian. Intermasa, Jakarta.

Tanya, B. L., Simanjuntak, Y. N., \& Hage, M. Y. (2010). Teori Hukum : Strategi Tertib Manusia Lintas Ruang dan Generasi. Genta Publishing.

Tjoanda, M., Hetharie, Y., Pariela, M. V. G., \& Sopamena, R. F. (2021). Covid-19 sebagai Bentuk Overmacht dan Akibat Hukumnya Terhadap Pelaksanaan Perjanjian Kredit. SASI, 27(1), 93-101. https:// doi.org/10.47268/sasi.v27i1.447

Widjaja, G. (2017). The Application and Implementtation of MOU in Indonesian Business Practices. International Journal of Business, Economics and Law, 13(4), 60-64. https:// www.ijbel.com/ previous-issues/august-2017/vol-13-august-2017-issue-4law/

Wignojodiputro, S. (1995). Pengantar Ilmu Hukum. Gunung Agung.

Yuanitasari, D., \& Kusmayanti, H. (2020). Pengembangan Hukum Perjanjian Dalam Pelaksanaan Asas Itikad Baik Pada Tahap Prakontraktual. ACTA DIURNAL Jurnal Ilmu Hukum Kenotariatan, 3(2), 292-304. http://jurnal.fh.unpad.ac.id/index.php/acta/article/view/228 